\title{
Resistance of Soil Organic Matter in "Humic A Horizons" of the Mountainous Region in the State of Rio De Janeiro
}

\author{
Ademir Fontana $^{1}$ (D), Marcos Gervasio Pereira ${ }^{2}$ (D), \\ Fabiano de Carvalho Balieiro ${ }^{1}$, Cesar da Silva Chagas ${ }^{1}$, \\ Guilherme Kangussu Donagemma ${ }^{1}$, Lucienne Silva de Oliveira ${ }^{3}$ \\ ${ }^{1}$ Embrapa Solos - CNPS, Rio de Janeiro/RJ, Brasil \\ ${ }^{2}$ Universidade Federal Rural do Rio de Janeiro - UFRRJ, Seropédica/RJ, Brasil \\ ${ }^{3}$ Independent researcher, Mangaratiba/RJ, Brasil
}

\begin{abstract}
Soils with high organic carbon content, such as those with "humic A horizon", occur in different regions of Brazil. This study aimed to determine the quantitative and qualitative characteristics of organic matter regarding the humic A horizon under different land uses in Bom Jardim, in Rio de Janeiro State, Brazil. Samples from forest, pasture, Eucalyptus plantation, coffee cultivation, olericulture, and also passion fruit soils were sampled and analyzed. In October 2011, undisturbed samples from humic A horizons, were collected for soil density analysis. In addition, disturbed samples were collected for the determination of organic carbon $\left(\mathrm{C}_{\text {org }}\right)$ content, total carbon, humic substance fractions contents and natural abundance of ${ }^{13} \mathrm{Carbon}\left(\delta^{13} \mathrm{C}\right)$. Low $\mathrm{C}_{\text {org }}$ contents were observed in areas under olericulture, pasture and passion fruit cultivation. The fulvic acid fraction was higher than other fractions, regardless of land use. The small variability in $\delta^{13} \mathrm{C}$ indicated maintenance of original $\mathrm{C}_{\text {org }}$ and suggest high resistance of Soil Organic Matter in humic A horizons.
\end{abstract}

Keywords: organic carbon, humic substances, isotopic composition. 


\section{INTRODUCTION}

Mountain farming systems are very common worldwide. Although generally small-scale and family-run systems ensure food security for thousands of people, as well as protect the environment, in other words, beautify rural landscapes, these systems also provide various ecosystem services (Kohler \& Romeo, 2014). Mountain areas, which vary greatly in terms of relief patterns, soils, and cultures, are vulnerable to degradation. Some soil classes are more resilient to organic matter loss owing to agricultural interventions and low-temperature effects (Buol \& Eswaran, 2000). Cultural practices, such as no-tillage farming, crop rotation and agroforestry, stabilize macroaggregates in the soil and reduce carbon loss.

In the state of Rio de Janeiro, Brazil, mountain farming is frequently carried out in soils with humus-rich topsoil, that is, in humic A horizons. According to the Brazilian Soil Classification System, the humic A horizon is a thick, dark-colored layer with high organic carbon content and low base saturation (Santos et al., 2018). These unique characteristics are a reflection of soil formation, landscape evolution and cultural practices (Volkoff et al., 1984; Benites, 2002; Dias et al., 2003; Dalmolin et al., 2006; Silva et al., 2007; Calegari, 2008; Fontana et al., 2010, 2017).

The humic A horizon can be considered as a relict paleosol. It was formed in past climates under conditions that favored high accumulation of organic matter, mainly graminoids in dry climates between the early-Pleistocene and mid-Holocene (Calegari, 2008). According to Buol \& Eswaran (2000), Calegari (2008), and Fontana et al. (2017), its occurrence is a result of the formation of stable organo-mineral complexes that protect Soil Organic Matter (SOM) from decomposition and against water erosion caused by its convex relief.

SOM is an important component of the soil and environment and it participates in the regulation of nutrient dynamics, soil aggregation, and greenhouse gas (GHG) emission. This parameter is an indicator of soil quality because it is related to different soil properties and processes, such as aeration, gas exchange, microbial activity and diversity, root growth, cation exchange capacity (CEC), and nutrient cycling (Doran \& Parkin, 1994; Feller \& Beare, 1997; Haynes, 2000; Dominati et al., 2010).
This study hypothesizes that the resilience of the humic A horizon is affected by agricultural practices, leading to modifications in the level and composition of SOM in areas subject to high-impact management practices. To test this hypothesis, the aim of this work was to evaluate the quantitative and qualitative characteristics of SOM in the humic A horizon under different uses in the state of Rio de Janeiro, Brazil.

\section{MATERIAL AND METHODS}

This study was carried out in Bom Jardim, located in the Pito Aceso microbasin $\left(22^{\circ} 15^{\prime} 17^{\prime \prime}\right.$ and $\left.42^{\circ} 18^{\prime} 09^{\prime \prime}\right)$ in the mountainous region of the state of Rio de Janeiro, Brazil. The local relief is characterized by rugged topography including slopes of various altitudes and narrow valleys; the elevation varies between 640 and 1,270 $\mathrm{m}$ above sea level. More information on local relief, geology, climate, vegetation, and land uses (P05, Eucalyptus plantation; P09, olericulture; P12, pasture; P13, coffee cultivation; and $\mathrm{P} 35$, passion fruit cultivation) can be found in Chagas et al. (2012) and Fontana et al. (2017).

Six areas under different uses were selected: 1) eucalyptus (Eucalyptus sp.) - a 3-year-old plantation associated with leaf litter covering the soil surface; 2) olericulture - "cassava" (Manihot esculenta) cultivation was being managed using mechanical tillage and weed control practices were established; 3) pasture (Brachiaria decumbens) that was put out under moderate grazing; 4) coffee (Coffea arabica) planted in rows; 5) passion fruit (Passiflora edulis) planted in rows; and 6) a fragment of Atlantic forest at an medium stage of regeneration (Figure 1).

The soil sampling and the field evaluations were performed in October 2011. In each area, a trench was opened and the horizons were separated. Samples were collected and described morphologically according to Santos et al. (2013) and classified according to the Brazilian Soil Classification System (Santos et al., 2018). From each horizon, undisturbed samples were collected using a $100 \mathrm{~cm}^{-3}$ ring for the analysis of soil density, and disturbed samples were collected for the determination of organic carbon $\left(\mathrm{C}_{\mathrm{org}}\right)$ content, total carbon (TC) content, humic substance fractions, and carbon-13 natural abundance $\left(\delta^{13} \mathrm{C}\right)$. 


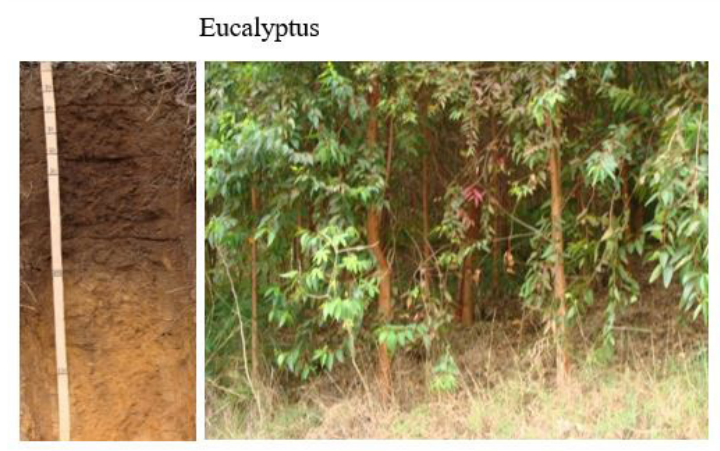

Pasture


Passion fruit
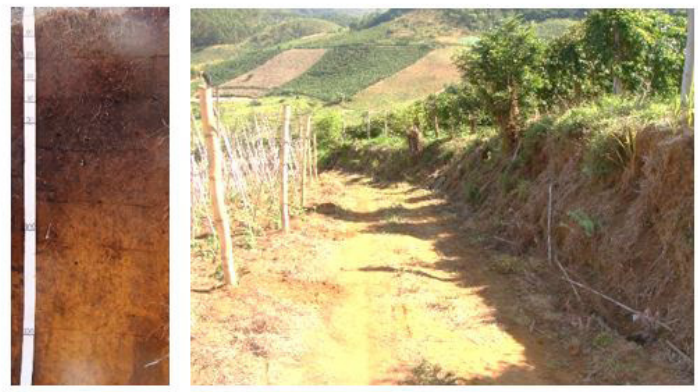

Olericulture


Coffee
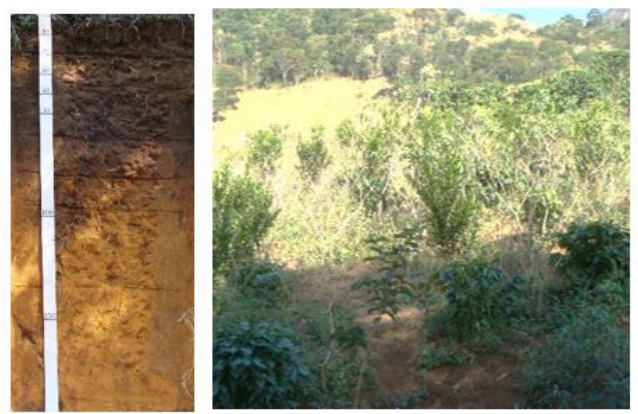

Forest
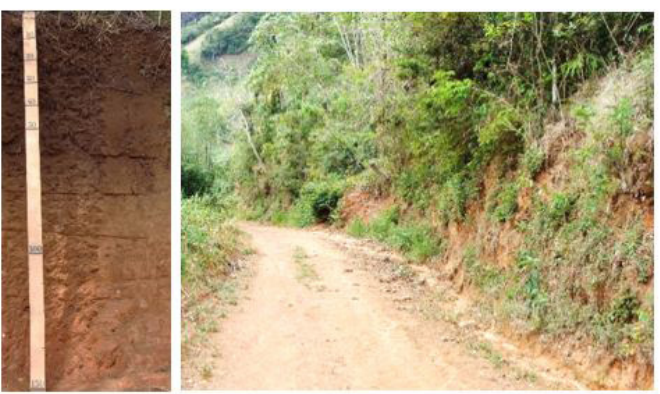

Figure 1. Soil profiles, landscape and use in each study area of "Pito Aceso" microbasin, situated in Bom Jardim, in the state of Rio de Janeiro. Photographs were taken by Cesar da Silva Chagas and Ademir Fontana.

Undisturbed soil samples were oven dried at $105^{\circ} \mathrm{C}$ for $24 \mathrm{~h}$. Soil density was calculated by dividing soil dry weight by the ring volume. Disturbed samples were oven dried at $50{ }^{\circ} \mathrm{C}$, de-clumped, and sieved through $2 \mathrm{~mm}$ mesh sieve. $\mathrm{C}_{\text {org }}$ content was determined by wet oxidation with potassium dichromate $\left(\mathrm{K}_{2} \mathrm{Cr}_{2} \mathrm{O}_{7}\right)$ solution in acidic medium and titration of ferrous ammonium sulfate (Mohr's salt), both described in Teixeira et al. (2017). TC content was determined by the dry combustion method. Briefly, $0.5 \mathrm{~g}$ of the sample was combusted at $1200^{\circ} \mathrm{C}$ under oxygen $\left(\mathrm{O}_{2}\right)$ atmosphere (99.97\%). Carbon dioxide $\left(\mathrm{CO}_{2}\right)$ was quantified using a non-dispersive infrared detector (multi EA ${ }^{\circledR} 2000$,
Analytik Jena, Jena, Alemanha). Calcium carbonate $\left(\mathrm{CaCO}_{3}\right)$ with a carbon (C) content of $120 \mathrm{~g} \mathrm{~kg}^{-1}$ was used as standard. The $\mathrm{C}$ stock was determined according to Ellert \& Bettany (1995).

Chemical fractionation of soil organic matter was carried out in acidic and basic media, and $\mathrm{C}_{\text {org }}$ content was determined in the Fulvic Acid (FAF), Humic Acid (HAF), and humin (HUMIN) fractions (Benites et al., 2017). Briefly, $1.0 \mathrm{~g}$ of soil sample was added to $20 \mathrm{~mL}$ of $0.1 \mathrm{~mol} \mathrm{~L}^{-1}$ sodium hydroxide $(\mathrm{NaOH})$ solution after $24 \mathrm{~h}$, the alkaline extract was separated from the residue by centrifugation at $5,000 \mathrm{~g}$ for $30 \mathrm{~min}$. Another extraction was performed, resulting in a final volume 
of alkaline extract of $40 \mathrm{~mL}$. The $\mathrm{pH}$ of the alkaline extract was adjusted to $1.0 \pm 0.1$ using $20 \%$ of sulfuric acid $\left(\mathrm{H}_{2} \mathrm{SO}_{4}\right)$ solution. The mixture rested for $18 \mathrm{~h}$ in a refrigerator, and the precipitate (HAF) was separated from the soluble fraction (FAF) by filtration. Samples were completed to $50 \mathrm{~mL}$ with distilled water.

The $\mathrm{C}_{\text {org }}$ contents of FAF and HAF were determined by adding $1.0 \mathrm{~mL}$ of $0.042 \mathrm{~mol} \mathrm{~L}^{-1} \mathrm{~K}_{2} \mathrm{Cr}_{2} \mathrm{O}_{7}$ and $5.0 \mathrm{~mL}$ of concentrated sulfuric acid $\left(\mathrm{H}_{2} \mathrm{SO}_{4}\right)$ to $5.0 \mathrm{~mL}$ of each extract, placing the solutions in a block digester at $150^{\circ} \mathrm{C}$ for $30 \mathrm{~min}$, and subsequently titrating with $0.0125 \mathrm{~mol}$ $\mathrm{L}^{-1}$ ferrous sulfate ammonium. The insoluble fraction (HUMIN) was oven dried and added to $5.0 \mathrm{~mL}$ of $0.1667 \mathrm{~mol} \mathrm{~L}^{-1} \mathrm{~K}_{2} \mathrm{Cr}_{2} \mathrm{O}_{7}$ and $10.0 \mathrm{~mL}$ of concentrated sulfuric acid. Block digestion was carried out at $150^{\circ} \mathrm{C}$ for $30 \mathrm{~min}$, followed by titration with $0.25 \mathrm{~mol} \mathrm{~L}^{-1}$ ferrous ammonium sulfate and ferroin indicator solution (Yeomans \& Bremner, 1988). The $\mathrm{C}_{\text {org }}$ contents of FAF, HAF, and HUMIN were determined, and the HAF/FAF ratio calculated (Benites et al., 2017). The percentage contribution of each fraction to TC content was also determined (\%FAF, \%HAF, and \%HUMIN).

The natural abundance of ${ }^{13} \mathrm{C}$ was determined using a mass spectrometer and the international standard Pee Dee Belemnite (PDB) was also used (Craig, 1957). Results are expressed as $\delta^{13} \mathrm{C}$, according to the equation $\delta^{13} \mathrm{C} \%=10^{3} \times\left(R_{\text {sample }}-R_{\text {standard }}\right) / R_{\text {standard }}$, where $R_{\text {sample }}$ is the ${ }^{13} \mathrm{C} /{ }^{12} \mathrm{C}$ ratio of the sample and $R_{\text {standard }}$ is the ${ }^{13} \mathrm{C} /{ }^{12} \mathrm{C}$ ratio of the standard.

\section{RESULTS AND DISCUSSION}

\subsection{Variability in soil $C_{\text {org }}$ content and humic properties}

$\mathrm{C}_{\text {org }}$ contents in soil ranged from 10.5 to $30.1 \mathrm{~g} \mathrm{~kg}^{-1}$ (Table 1). $\mathrm{C}_{\text {org }}$ values were highest in shallow horizons, however, the $\mathrm{C}_{\text {org }}$ values have been decreasing according to the soil depth (Table 1). It was found that the variation of the $\mathrm{C}_{\text {org }}$ content is not consistent with land use or

Table 1. Organic carbon content and humic substance fractions from humic A horizons in each study area in the "Pito Aceso" microbasin, Bom Jardim, in the state of Rio de Janeiro, Brazil.

\begin{tabular}{|c|c|c|c|c|c|c|c|}
\hline \multirow{2}{*}{ Uses } & \multirow{2}{*}{ Horizon } & Depth & $\mathrm{C}_{\text {org }}$ & FAF & HAF & HUMIN & \multirow{2}{*}{$\frac{\text { HAF/FAF }}{-}$} \\
\hline & & $\mathrm{cm}$ & $\mathrm{g} \mathrm{kg}^{-1}$ & & $\%$ & & \\
\hline \multirow{4}{*}{ Eucalyptus plantation } & Ap & $0-18$ & 30.1 & 17 & 23 & 46 & 1.4 \\
\hline & A1 & $18-45$ & 22.8 & 12 & 26 & 45 & 2.1 \\
\hline & A2 & $45-85$ & 22.8 & 12 & 15 & 39 & 1.3 \\
\hline & $\mathrm{AB}$ & $85-100$ & 14.8 & 11 & 16 & 39 & 1.4 \\
\hline \multirow{4}{*}{ Olericulture } & Ap & $0-40$ & 15.6 & 22 & 20 & 29 & 0.9 \\
\hline & A1 & $40-65$ & 10.5 & 25 & 14 & 26 & 0.6 \\
\hline & A2 & $65-80$ & 11.1 & 11 & 16 & 66 & 1.5 \\
\hline & $\mathrm{AB}$ & $80-102$ & 10.9 & 25 & 23 & 53 & 0.9 \\
\hline \multirow{3}{*}{ Pasture } & Ap & $0-23$ & 15.9 & 15 & 18 & 26 & 1.2 \\
\hline & Al & $23-58$ & 11.1 & 22 & 13 & 46 & 0.6 \\
\hline & $\mathrm{A} 2$ & $58-95$ & 11.0 & 15 & 18 & 25 & 1.2 \\
\hline \multirow{4}{*}{ Coffee cultivation } & Ap & $0-19$ & 23.1 & 20 & 13 & 61 & 0.6 \\
\hline & $\mathrm{A} 1$ & $19-32$ & 20.5 & 18 & 13 & 43 & 0.7 \\
\hline & $\mathrm{A} 2$ & $32-60$ & 20.6 & 9 & 13 & 31 & 1.5 \\
\hline & $\mathrm{AB}$ & $60-79$ & 12.9 & 26 & 20 & 25 & 0.8 \\
\hline \multirow{4}{*}{ Passion fruit } & Ap & $0-20$ & 17.2 & 13 & 13 & 31 & 1.0 \\
\hline & $\mathrm{A} 1$ & $20-38$ & 15.8 & 15 & 15 & 29 & 1.0 \\
\hline & $\mathrm{A} 2$ & $38-61$ & 17.2 & 24 & 26 & 11 & 1.1 \\
\hline & $\mathrm{AB}$ & $61-85$ & 10.9 & 15 & 23 & 43 & 1.6 \\
\hline \multirow{4}{*}{ Forest } & A1 & $0-22$ & 27.3 & 8 & 6 & 79 & 0.8 \\
\hline & $\mathrm{A} 2$ & $22-40$ & 27.1 & 8 & 6 & 76 & 0.7 \\
\hline & A3 & $40-65$ & 22.1 & 10 & 9 & 57 & 0.9 \\
\hline & $\mathrm{AB}$ & $65-75$ & 12.8 & 13 & 15 & 49 & 1.1 \\
\hline
\end{tabular}

$\mathrm{C}_{\text {org }}=$ organic carbon; FAF = fulvic acid fraction; HAF = humic acid fraction; HUMIN = humin fraction 
type of crop. For instance, $\mathrm{C}_{\text {org }}$ values were in average $11 \%, 29 \%, 42 \%$ and $50 \%$ lower in soils under coffee cultivation, passion fruit, olericulture and pasture, respectively, than in soil under forest (Table 1 and Figure 2). In other hand, the humic A horizon from Eucalyptus plantation presented as an average of 3\% more $\mathrm{C}_{\text {org }}$ than soil under forest (Table 1).

These differences in $\mathrm{C}_{\text {org }}$ content between soil layers can be attributed to variability in root contribution between areas (root/shoot ratio), such as, the effects of root exudates on soil microbial activity, and differences in water vapor permeability (Wang et al., 2018; Sokol \& Bradford, 2019). It seems evident that a diverse forest ecosystem allows greater $\mathrm{C}$ stabilization at depth, and these data corroborated with the role of forests in $\mathrm{C}$ sequestration (Bonan, 2008). Nevertheless, $\mathrm{C}_{\text {org }}$ contents in soils under pasture and crop correspond to SOM contents within the normal range for fertile soil (Freire et al., 2013), indicating good stability or resilience of $\mathrm{C}_{\text {org }}$ in the sampled profiles.


Figure 2. Depth distribution of the organic carbon contents in humic A horizons in "Pito Aceso" and in other municipalities of the state of Rio de Janeiro. (1) Present study; (2) Calegari (2008); (3) Chagas et al. (2012).
In previous studies, Calegari (2008) and Chagas et al. (2012) observed in the same humic A horizon from the Southern, Southeastern and Northeastern regions similar variations and $\mathrm{C}_{\text {org }}$ values between 5.9 and $68.9 \mathrm{~kg} \mathrm{~g}^{-1}$ (Figure 2). In the Agreste region of Pernambuco in Brazil, Pessoa et al. (2012) also found variations in $\mathrm{C}_{\text {org }}$ content among soils under different uses. In their study, $\mathrm{C}_{\text {org }}$ values ranged from 15.0 to $43.7 \mathrm{~g} \mathrm{~kg}^{-1}$ at the $10 \mathrm{~cm}$ depth. Native forest soils had the highest $\mathrm{C}_{\text {org }}$ content, followed by soils under "capoeira" vegetation, 25- and 30-year old pastures and annual cropping systems.

Although the use of agriculture is admittedly deleterious to soil C stocks (Carvalho et al., 2010; Coutinho et al., 2014), in pastures, I could be found distinct results when compared to other authors who reviewed the world literature (Guo \& Gifford, 2002), or even had been worked more locally (in the Atlantic Forest biome) (Tarré et al. 2001; Cerri et al., 2007), as they detected an increase in $\mathrm{C}$ levels and stocks after converting forest to pasture; on the other hand, this change has not occurred for soils with humic $\mathrm{A}$ horizon. The evidence of susceptibility to $\mathrm{C}-\mathrm{CO}_{2}$ loss from these soils seemed to be relevant for these soils, but more soils must be sampled and characterized.

The analysis of humic substance provides information on the degree of humification and $\mathrm{C}$ stability, complementing the results of SOM and $\mathrm{C}_{\text {org }}$ analysis. There was wide variability in humic properties within and between soil fractions, regardless of land use or crop type. HUMIN varied from 11 to $79 \%$, but most results were above 25\%. HAF ranged from 6 to $26 \%$, and FAF from 8 to $25 \%$ (Table 1). The HAF/FAF ratio is an indicator of the quality and origin of SOM. An HAF/FAF ratio greater than 1.0 for surface horizons indicates that soil use or changes in vegetation cover have been decreased the supply of fresh organic material into the soil. Surface horizons had lower HAF/FAF ratios than deeper horizons. Forest, olericulture, and coffee cultivation areas had topsoil HAF/FAF ratios below 1.0 .

TC contents were used to estimate the $\mathrm{C}$ stock in humic A horizons (Table 2). The $\mathrm{C}$ stock varied greatly between sites: soil under passion fruit cultivation showed a C stock of $162.64 \mathrm{Mg} \mathrm{ha}^{-1}$, whereas soil under Eucalyptus plantation had a C stock of $284.69 \mathrm{Mg} \mathrm{ha}^{-1}$. These values are higher than those reported in previous studies for soils subjected to different uses in low-altitude regions 
Table 2. Total carbon and carbon stock from humic A horizons and total sock in each study area in the "Pito Aceso" microbasin, situated in Bom Jardim, in the state of Rio de Janeiro, Brazil.

\begin{tabular}{|c|c|c|c|c|c|}
\hline \multirow{2}{*}{ Uses } & \multirow{2}{*}{ Horizon } & \multirow{2}{*}{$\begin{array}{c}\mathrm{TC} \\
\mathrm{g} \mathrm{kg}^{-1}\end{array}$} & \multirow{2}{*}{$\frac{\text { BD }}{\mathrm{Mg} \mathrm{m}^{-3}}$} & Horizon Stock & Total Stock \\
\hline & & & & \multicolumn{2}{|c|}{$-\mathrm{Mg} \mathrm{ha}^{-1}$} \\
\hline \multirow{4}{*}{ Eucalyptus plantation } & Ap & 45.0 & 0.79 & 63.99 & 284.69 \\
\hline & A1 & 31.4 & 0.82 & 69.52 & \\
\hline & $\mathrm{A} 2$ & 30.3 & 0.92 & 111.50 & \\
\hline & $\mathrm{AB}$ & 22.8 & 1.16 & 39.67 & \\
\hline \multirow{4}{*}{ Olericulture } & Ap & 19.6 & 1.07 & 83.89 & 201.47 \\
\hline & A1 & 18.5 & 1.09 & 50.41 & \\
\hline & $\mathrm{A} 2$ & 16.8 & 1.28 & 32.26 & \\
\hline & $\mathrm{AB}$ & 12.8 & 1.24 & 34.92 & \\
\hline \multirow{3}{*}{ Pasture } & Ap & 19.2 & 1.25 & 55.20 & 176.26 \\
\hline & A1 & 13.3 & 1.15 & 53.53 & \\
\hline & A2 & 16.9 & 1.08 & 67.53 & \\
\hline \multirow{4}{*}{ Coffee cultivation } & Ap & 26.6 & 1.08 & 54.58 & 208.10 \\
\hline & $\mathrm{A} 1$ & 25.3 & 1.13 & 37.17 & \\
\hline & A2 & 23.0 & 1.21 & 77.92 & \\
\hline & $\mathrm{AB}$ & 15.8 & 1.28 & 38.43 & \\
\hline \multirow{4}{*}{ Passion fruit } & Ap & 22.4 & 1.01 & 45.25 & 162.64 \\
\hline & A1 & 20.6 & 1.00 & 37.08 & \\
\hline & A2 & 22.7 & 0.91 & 47.51 & \\
\hline & $\mathrm{AB}$ & 13.4 & 1.02 & 32.80 & \\
\hline \multirow{4}{*}{ Forest } & $\mathrm{A} 1$ & 32.1 & 0.89 & 62.85 & 185.51 \\
\hline & A2 & 29.8 & 0.94 & 50.42 & \\
\hline & A3 & 22.4 & 1.02 & 57.12 & \\
\hline & $\mathrm{AB}$ & 12.7 & 1.19 & 15.11 & \\
\hline
\end{tabular}

$\mathrm{TC}=$ total carbon; $\mathrm{BD}=$ bulk density.

(Vieira et al., 2011; Villela et al., 2012; Coutinho et al., 2014; Martins et al., 2015). The C stock changes in the humic A horizon can be a result of several factors, including inherent characteristics related to the formation of the soil, as well as past and present land use and management practices-from wood harvesting since colonization and coffee and cattle production days to modern times.

Calegari (2008) analyzed C contents in humic A horizon of other regions in the state of Rio de Janeiro and estimated higher TC stocks values than those found in this study: $368.84 \mathrm{Mg} \mathrm{ha}^{-1}$ for pasture and 613.82 $\mathrm{Mg} \mathrm{ha}^{-1}$ for secondary forest. The author has also been studied soil profiles submitted to different uses in other regions of the country, and this author could find TC stock values ranging from 251.12 to $500.82 \mathrm{Mg} \mathrm{ha}^{-1}$. This large variability in $\mathrm{C}$ stock shows that soils with humic A horizon differ greatly in $\mathrm{C}$ accumulation potential, in agreement with their differences in formation, vegetation cover, landscape evolution history, and water erosion susceptibility.

\section{2. ${ }^{13} \mathrm{C}$ natural abundance in Latossolos with humic A horizon}

$\delta^{13} \mathrm{C}$ values ranged from -25.73 to $-21.33 \%$ o (Figure 3). It was found that both past (deep horizons) and present vegetation (surface horizon) were formed predominantly, but not exclusively, by $\mathrm{C}_{3}$. A combination of $\mathrm{C}_{4}$ and $\mathrm{C}_{3}$ plants was detected in all soils. Calegari (2008) reported similar data in a study that evaluated the occurrence and paleoenvironmental significance of A humic horizon in Latossolos (Oxisols). That study, by evaluating the data of SOM isotope and phytolith assemblages indicated that this type of soil was formed under a less dense vegetation than the present one. Probably, owing to the mixture of $\mathrm{C}_{3}$ and $\mathrm{C}_{4}(\sim-22 \%)$ plants and to the more contribution of $\mathrm{C}_{3}$ in the Southeast region. In addition, the author concluded that, from the late Holocene, it could be 


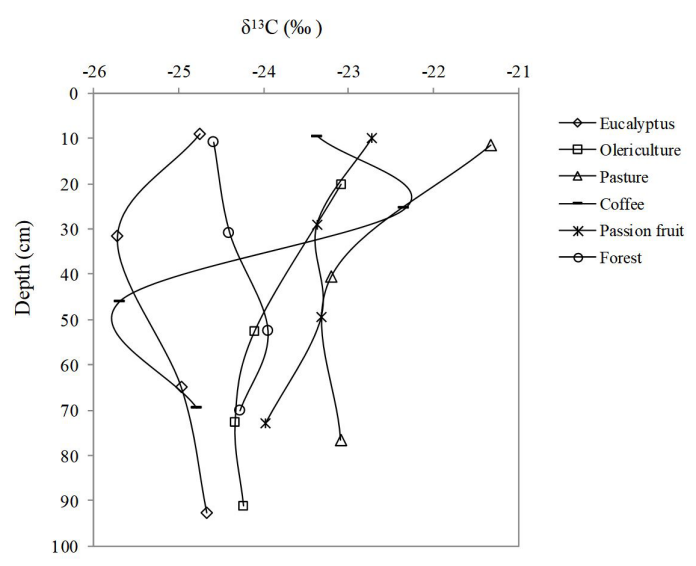

Figure 3. Depth distribution of the carbon-13 natural abundance $\left(\delta^{13} \mathrm{C}\right)$ from humic A horizons in each study area in the "Pito Aceso" microbasin, situated in Bom Jardim, in the state of Rio de Janeiro, Brazil.

found a more ${ }^{13} \mathrm{C}$ depleted values ( - 25\%o), suggesting the expansion of the tropical and subtropical forests, probably associate to a humid and warm climate.

The small variability in $\delta^{13} \mathrm{C}$ indicated maintenance of original $\mathrm{C}$, as even secondary forest areas converting into grass areas for 20 or 30 years had low $\mathrm{C}_{4}$ contribution. Kuzyakov et al. (2000) described soil effects whereby changes in organic matter turnover that occurs due to soil interventions, such as mechanical disturbance or addition of fertilizers, crop residues, or organic compounds. According to an ecological perspective, negative priming effects are more important than positive one because they have an impact on original $\mathrm{C}$ conservation. Thus, it is important to consider the original $\mathrm{C}$ stocks equivalent to those found in forest fragments, a characteristic that can be observed is the resistance of these soils to $\mathrm{C}$ losses.

\section{CONCLUSIONS}

Soils under intensive agriculture, such as pasture and olericulture systems, had a greater C loss than soils under secondary forest cover or Eucalyptus plantation. There was wide variability in humic substance fractions between and within areas and horizons. Surface layers had higher FAF, regardless of land use or crop type. $\delta^{13} \mathrm{C}$ values showed little variability between soils under different uses, which indicates relative stability of the landscape and of the maintenance of soil C quality, with relative resistance of organic matter in the humic A horizon. Efforts in agriculture conservation practices should be encouraged to minimize $C$ losses in these soils, especially regarding the perspective of global warming.

\section{ACKNOWLEDGEMENTS}

The authors thank the Rio de Janeiro State Research Foundation - FAPERJ (Grant no. E-26/111.934/2011, project entitled "Dinâmica dos solos com elevados teores de matéria orgânica da região serrana do estado do Rio de Janeiro" for the financial support, and the Brazilian National Council for Scientific and Technological Development - Conselho Nacional de Desenvolvimento Científico e Tecnológico (CNPq) for supporting the scientific initiation sholarship (Grant no. $121768 / 2011-2$ )

\section{SUBMISSION STATUS}

Received: 12 july, 2019

Accepted: 27 dec., 2019

\section{CORRESPONDENCE TO}

\section{Ademir Fontana}

Embrapa Solos - CNPS, Rua Jardim Botânico, CEP 22460-000, Rio de Janeiro, RJ, Brasil e-mail: ademir.fontana@embrapa.br

\section{FINANCIAL SUPPORT}

Fundação Carlos Chagas Filho de Amparo à Pesquisa do Estado do Rio de Janeiro (Grant Award Number: E-26/111.934/2011). Conselho Nacional de Desenvolvimento Científico e Tecnológico (Grant/Award Number: 121768/2011-2).

\section{REFERENCES}

Benites VM, Machado PLOA, Madari BE, Fontana A. Fracionamento químico da matéria orgânica. In: Teixeira PC, Donagemma GK, Fontana A, Teixeira W, editors. Manual de métodos de análise de solo. 3. ed. rev. e ampl. Brasília: Embrapa; 2017.

Benites VM. Caracterização de solos e das substâncias húmicas em complexo rupestre de altitude [tese]. Viçosa: 
Departamento de Solos, Universidade Federal de Viçosa; 2002.

Bonan GB. Forests and climate change: forcings, feedbacks, and the climate benefits of forests. Science 2008; 320(5882): 1444-1449. http://dx.doi.org/10.1126/science.1155121. PMid:18556546.

Buol SW, Eswaran H. Oxisols. Advances in Agronomy 2000; 68: 151-195. http://dx.doi.org/10.1016/S00652113(08)60845-7.

Calegari MR. Ocorrência e significado paleoambiental do horizonte a húmico em Latossolos [tese]. Piracicaba: Escola Superior de Agricultura "Luiz de Queiroz", Universidade de São Paulo; 2008.

Carvalho JLN, Raucci GS, Cerri CEP, Bernoux M, Feigl BJ, Wruck FJ et al. Impact of pasture, agriculture and crop-livestock systems on soil C stocks in Brazil. Soil \& Tillage Research 2010; 110(1): 175-186. http://dx.doi. org/10.1016/j.still.2010.07.011.

Cerri CEP, Sparovek G, Bernoux M, Easterling WE, Melillo JM, Cerri CC. Tropical agriculture and global warming: impacts and mitigation options. Scientia Agrícola 2007; 64(1): 83-99. http://dx.doi.org/10.1590/ S0103-90162007000100013.

Chagas CS, Calderano B Fo, Donagemma GK, Fontana A, Bhering SB. Levantamento semidetalhado dos solos da microbacia do Córrego do Pito Aceso, Município de Bom Jardim, região serrana do Estado do Rio de Janeiro - RJ [online]. Brasília: Embrapa; 2012 [cited 2019 July 12]. Available from: https://www.embrapa.br/buscade-publicacoes/-/publicacao/998391/levantamentosemidetalhado-dos-solos-da-microbacia-do-corrego-dopito-aceso-municipio-de-bom-jardim-regiao-serranado-estado-do-rio-de-janeiro---rj

Coutinho HLC, Noellemeyer E, Balieiro FC, Pineiro G, Fidalgo EC, Martius $\mathrm{C}$ et al. Impacts of land-use change on carbon stocks and dynamics in central-southern South American Biomes: Cerrado, Atlantic Forest and Southern Grasslands. In: Banwart SB, Noellemeyer E, Milne E, editors. Soil carbon science: management and policy for multiple benefits. 1st ed. Reino Unido: CABI; 2014.

Craig H. Isotopic standards for carbon and oxygen and correction factors for mass spectrometric analysis of carbon dioxide. Geochimica et Cosmochimica Acta 1957; 12(1-2): 133-149. http://dx.doi.org/10.1016/0016-7037(57)90024-8.

Dalmolin RSD, Gonçalves CN, Dick DP, Knicker H, Klamt E, Kögel-Knabner I. Organic matter characteristics and distribution in Ferralsol profiles of a climosequence in southern Brazil. European Journal of Soil Science 2006; 57(5): 644-654. http://dx.doi.org/10.1111/j.13652389.2005.00755.x.

Dias HCT, Schaefer CEGR, Fernandes EI Fo, Oliveira AP, Michel RFM, Lemos JB Jr. Caracterização de solos altimontanos em dois transectos no Parque Estadual do Ibitipoca (MG). Revista Brasileira de Ciência do Solo
2003; 27(3): 469-481. http://dx.doi.org/10.1590/S010006832003000300009 .

Dominati E, Patterson M, Mackay A. A framework for classifying and quantifying the natural capital and ecosystem services of soils. Ecological Economics 2010; 69(9): 18581868. http://dx.doi.org/10.1016/j.ecolecon.2010.05.002.

Doran JW, Parkin TB. Defining and assessing soil quality. In: Doran JW, Coleman DC, Bezdicek DF, Stewart BA, editors. Defining soil quality for a sustainable environment. Madison: Soil Science Society of America; 1994. (SSSA Special Publication; no. 35). http://dx.doi.org/10.2136/ sssaspecpub35.c1.

Ellert BH, Bettany JR. Calculation of organic matter and nutrients stored in soils under contrasting management regimes. Canadian Journal of Soil Science 1995; 75(4): 529-538. http://dx.doi.org/10.4141/cjss95-075.

Feller C, Beare MH. Physical control of soil organic matter dynamics in the tropics. Geoderma 1997; 79(1-4): 69-116. http://dx.doi.org/10.1016/S0016-7061(97)00039-6.

Fontana A, Chagas CS, Donagemma GK, Menezes AR, Calderano B Fo. Soils developed on geomorphic surfaces in the mountain region of the state of Rio de Janeiro. Revista Brasileira de Ciência do Solo 2017; 41: e0160574. http:// dx.doi.org/10.1590/18069657rbcs20160574.

Fontana A, Pereira MG, Anjos LHC, Benites VM. Quantificação e utilização das frações húmicas como característica diferencial em horizontes diagnósticos de solos brasileiros. Revista Brasileira de Ciência do Solo 2010; 34(4): 1241-1247. http://dx.doi.org/10.1590/S010006832010000400023.

Freire LR, Balieiro FC, Zonta E, Anjos LHC, Pereira MG, Lima E et al. Manual de calagem e adubação do Estado do Rio de Janeiro. Brasília: Embrapa; 2013.

Guo LB, Gifford RM. Soil carbon stocks and land use change: a meta analysis. Global Change Biology 2002; 8(4): 345360. http://dx.doi.org/10.1046/j.1354-1013.2002.00486.x.

Haynes RJ. Labile organic matter as an indicator of organic matter quality in arable and pastoral soils in New Zealand. Soil Biology \& Biochemistry 2000; 32(2): 211-219. http:// dx.doi.org/10.1016/S0038-0717(99)00148-0.

Kohler T, Romeo R. Mountains farming is family farming. In: Wymann von Dach S, Romeo R, Vita A, Wurzinger M, Kohler T, editors. Mountain farming is family farming: $a$ contribution from mountain areas to the International Year of Family Farming 2014. Rome: FAO, CDE, BOKU; 2014.

Kuzyakov Y, Friedel JK, Stahr K. Review of mechanisms and quantification of priming effects. Soil Biology \& Biochemistry 2000; 32(11-12): 1485-1498. http://dx.doi. org/10.1016/S0038-0717(00)00084-5.

Martins SC, Sousa E No, Piccolo MC, Almeida DQA, Camargo PB, do Carmo JB et al. Soil texture and chemical characteristics along an elevation range in the coastal Atlantic 
Forest of Southeast Brazil. Geoderma Regional 2015; 5: 106-116. http://dx.doi.org/10.1016/j.geodrs.2015.04.005.

Pessoa PMA, Duda GP, Barros RB, Freire MBGS, Nascimento CWA, Correa MM. Frações de carbono orgânico de um Latossolo Húmico sob diferentes usos no Agreste Brasileiro. Revista Brasileira de Ciência do Solo 2012; 36(1): 97-104. http://dx.doi.org/10.1590/S0100-06832012000100011.

Santos HG, Jacomine PKT, Anjos LHC, Oliveira VA, Lumbreras JF, Coelho MR et al. Sistema brasileiro de classificação de solos. 5. ed. rev. ampl. Brasília: Embrapa; 2018 .

Santos RD, Lemos RC, Santos HG, Ker JC, Anjos LHC, Shimizu SH. Manual de descrição e coleta de solo no campo. 6. ed. rev. ampl. Viçosa: Sociedade Brasileira de Ciência do Solo, Embrapa Solos; 2013.

Silva AC, Vidal Torrado P, González Perez M, Martin L No, Vasques FM. Relações entre matéria orgânica do solo e declividade de vertentes em topossequência de Latossolos do sul de Minas Gerais. Revista Brasileira de Ciência do Solo 2007; 31(5): 1059-1068. http://dx.doi.org/10.1590/ S0100-06832007000500022.

Sokol NW, Bradford MA. Microbial formation of stable soil carbon is more efficient from belowground than aboveground input. Nature Geoscience 2019; 12(1): 46-53. http://dx.doi.org/10.1038/s41561-018-0258-6.

Tarré R, Macedo R, Cantarutti RB, Rezende CP, Pereira $\mathrm{JM}$, Ferreira E et al. The effect of the presence of a forage legume on nitrogen and carbon levels in soils under Brachiaria pastures in the Atlantic forest region of the south of Bahia, Brazil. Plant and Soil 2001; 234(1): 15-26. http://dx.doi.org/10.1023/A:1010533721740.
Teixeira PC, Donagemma GK, Fontana A, Teixeira W. Manual de métodos de análise de solo [online]. 3. ed. rev. e ampl. Brasília, DF: Embrapa, 2017 [cited 2019 July 12]. Available from: https://www.infoteca.cnptia.embrapa.br/ handle/doc/1085209

Vieira SA, Alves LF, Duarte-Neto PJ, Martins SC, Veiga LG, Scaranello MA et al. Stocks of carbon and nitrogen and partitioning between above- and belowground pools in the Brazilian coastal Atlantic Forest elevation range. Ecology and Evolution 2011; 1(3): 421-434. http://dx.doi. org/10.1002/ece3.41. PMid:22393511.

Villela DM, Mattos EA, Pinto AS, Vieira SA, Martinelli LA. Carbon and nitrogen stock and fluxes in coastal Atlantic Forest of southeast Brazil: potential impacts of climate change on biogeochemical functioning. Brazilian Journal of Biology $=$ Revista Brasileira de Biologia 2012;72(3, Suppl.): 633-642. http://dx.doi.org/10.1590/ S1519-69842012000400003. PMid:23011294.

Volkoff B, Cerri CC, Melfi J. Húmus e mineralogia dos horizontes superficiais de três solos de campo de altitude dos Estados de Minas Gerais, Paraná e Santa Catarina. Revista Brasileira de Ciência do Solo 1984; 8: 277-283.

Wang Y, Li X, Dong W, Wu D, Hu C, Zhang Y et al. Depth-dependent greenhouse gas production and consumption in an upland cropping system in northern China. Geoderma 2018; 319: 100-112. http://dx.doi. org/10.1016/j.geoderma.2018.01.001.

Yeomans JC, Bremner JM. A rapid and precise method for routine determination of organic carbon in soil. Communications in Soil Science and Plant Analysis 1988; 19(13): 1467-1476. http://dx.doi.org/10.1080/00103628809368027. 